\title{
Metamorphism of the Kangâmiut dykes and the metamorphic and structural evolution of the southern Nagssugtoqidian boundary in the Itvidleq-Ikertôq region, West Greenland
}

\author{
John A. Korstgård
}

\begin{abstract}
The structural evolution of the Nagssugtoqidian mobile belt is characterised by reworking of pre-existing Archaean rocks. At the southern Nagssugtoqidian boundary swarms of basic dykes, the Kangâmiut dykes, intruded after the earliest Nagssugtoqidian movements. These dykes act as time markers separating tectono-metamorphic events and record degree and extent of post-dyke metamorphism and deformation.

The structural and metamorphic evolution at the southern Nagssugtoqidian boundary can be summarised as follows. The rocks now exposed were stabilised in granulite and amphibolite facies in Archaean times. Uplift brought the rocks under low amphibolite facies conditions. Subsequent deformation (Nag. 1) caused the retrogression to low amphibolite facies and transformed the rocks into strongly schistose rocks along ductile, transcurrent, E-W trending shear zones. The Nag. 1 deformation was followed by intrusion of the mainly NE trending Kangâmiut dykes. Later Nagssugtoqidian deformation (Nag. 2) affected country rocks with Nag. 1 fabrics as well as dykes and probably also Archaean gneisses unaffected by Nag. 1 deformation. In areas with intense Nag. 2 movements the deformation was characterised by ductile overthrusting towards the SSE along a linear zone striking ENE. New Nag. 2 fabrics were imposed on the country gneisses and dykes were transformed into strongly deformed amphibolites. The ductile overthrusting brought granulite facies rocks into juxtaposition with amphibolite facies rocks so that across the areas affected by Nag. 2 deformation a prograde metamorphic sequence with facies boundaries parallel to the overthrusting zone was established.
\end{abstract}

\section{Introduction}

In the area between Itivdleq and Holsteinsborg (fig. 1) the Kangâmiut dykes are found in a variety of structural and petrographical modifications. Around Itivdleq undeformed and unmetamorphosed dolerite dykes are found together with partly deformed and metamorphosed dykes, but where deformation of dykes occur, it is not related to any regional deformation observable in the country gneisses. In contrast to this, the dykes north of Itivdleq, between Kangerdluarssuk and Ikertôq, are metamorphosed and deformed together with their country gneisses.

The partly deformed and metamorphosed dykes around Itivdleq provide excellent examples of how subophitic dolerite dykes are transformed into granoblastic amphibolites either without or accompanied by strong deformation. However, this aspect will not be considered here. Instead, attention will be focused on the timing of the dyke intrusion in relation to deformational events around Itivdleq and on the regional metamorphism of dykes and 


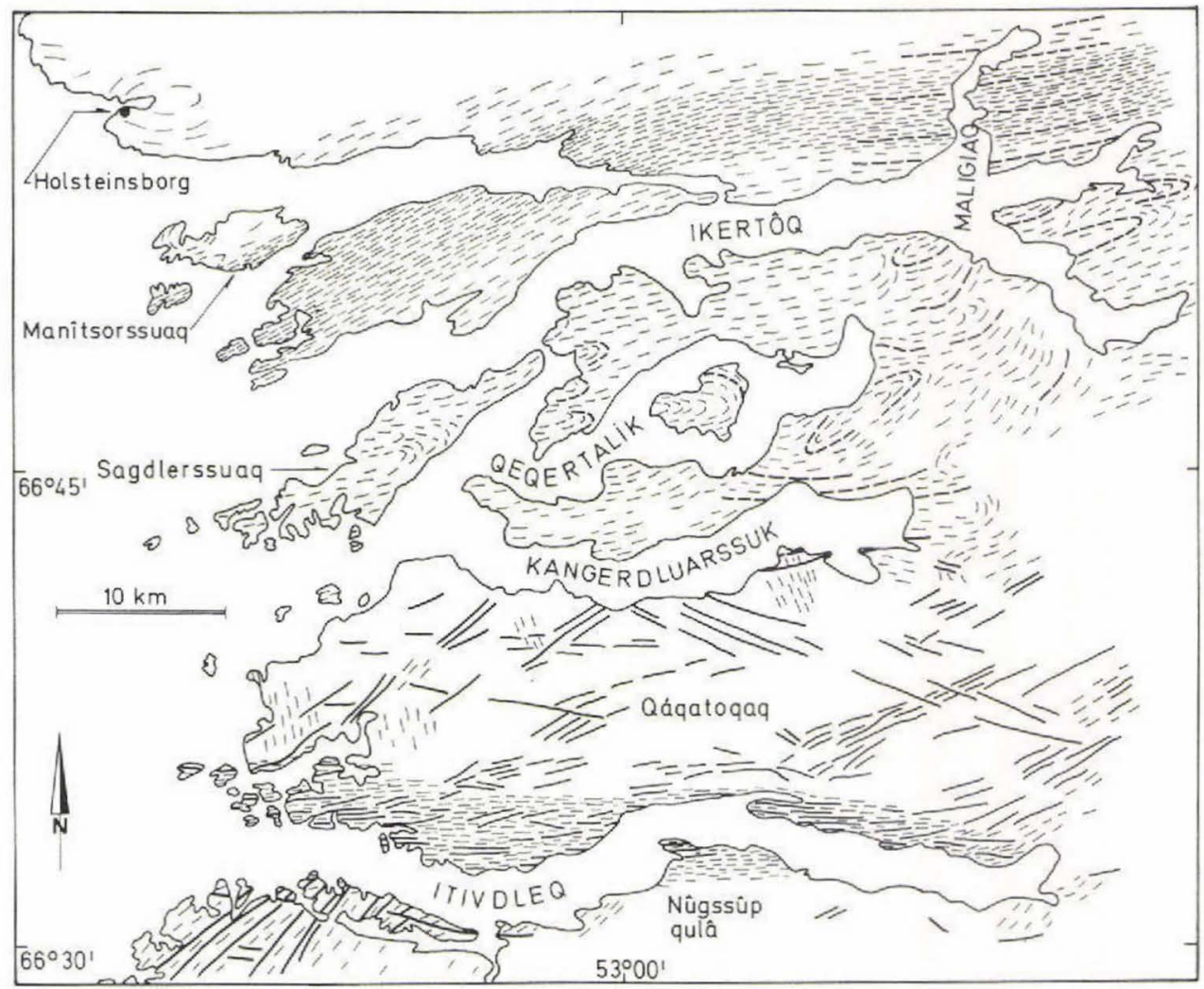

Fig. 1. Dyke and structural sketch map of the Itivdleq-Ikertôq region. Thin dashed lines: structural trends in country gneisses. The intensity of lines reflects degree of deformation. Thick full lines: undeformed dolerite dykes. Thick dashed lines: deformed and metamorphosed dolerite dykes. Only a few of the deformed dykes are shown on the map.

country rocks north of Itivdleq with the aim of providing a basis for a discussion of the structural and metamorphic evolution of the southern boundary of the Nagssugtoqidian mobile belt.

The intrusion of the Kangâmiut dykes in the region described here was predated by strong deformation and metamorphism (Nag. 1) of Archaean country rocks in some areas. Following dyke intrusion the country rocks, in particular in the northern part of the region, again suffered strong deformation and metamorphism (Nag. 2), this time involving the Kangâmiut dykes. Clearly the very convenient time of intrusion of the dykes has been an invaluable aid in unravelling the various deformational and metamorphic events in the area. 


\section{Archaean}

Archaean rocks in the region are found north and south of Itivdleq, in Qáqatoqaq and Nûgssûp qulâ respectively (fig. 1). The metamorphic grade of these rocks is granulite facies in the western part and amphibolite facies in the eastern part. They are mainly quartzofeldspathic gneisses ( + biotite \pm hornblende \pm hypersthene) of tonalitic to granodioritic composition containing numerous mafic pods and lenses consisting mainly of plagioclase and hornblende, and, in the western part, pyroxenes. The gneisses have poorly developed planar fabrics trending mainly NE-SW in Nûgssûp qulâ and NW-SE in Qáqatoqaq.

\section{Nag. 1 metamorphism and deformation}

Along the north and south coast of Itivdleq the trend of the compositional layering and schistosity of the gneisses is uniformly E-W and subvertical (fig. 1). This broad band (c. 6 $\mathrm{km}$ in width) is made up of a number of ductile shear zones which collectively constitute the Itivdleq shear zone. The sense of shear in the shear zones is invariably dextral, the shear plane subvertical, and the movement direction, as estimated from stretching lineations on schistosity planes, plunges shallowly or moderately steep to the west.

In the Itivdleq shear zone the quartzo-feldspathic gneisses are retrogressed from granulite or amphibolite facies to low amphibolite facies (epidote-amphibolite). The retrogression is clearly connected with the shearing and is confined to the zones of strong deformation and their vicinity. The shearing and retrogression not only involves a development of hydrous mafic minerals at the expense of anhydrous minerals, but also several microstructural and mineralogical changes. Orthopyroxene disappears from the granulite facies gneisses, hornblende changes in colour from brown-green to blue-green, biotite changes from red-brown to green-brown, muscovite, epidote and alkali-feldspar appear, the anorthite content of plagioclase decreases from 30-40 per cent to around 25 per cent, and antiperthitic plagioclase disappears. The compositional changes in plagioclase are accompanied by a recrystallisation of plagioclase which results in the formation of new strain-free, polygonal grains and a reduction in grain size. Quartz also recrystallises to smaller polygonal grains. The strong planar and linear fabric produced in the sheared rocks is defined by preferred habit orientation of mafic minerals, mainly mica, and by aggregates of equidimensional grains of quartz and plagioclase.

The evolution of the Itivdleq shear zone is illustrated schematically in fig. 2 which shows vertical sections through the crust starting at the time when rocks in Qáqatoqaq and Nûgssûp qulâ were stabilised in granulite and amphibolite facies (fig. 2a). Between that time and the Nag. 1 shearing uplift took place whereby the granulite-amphibolite facies isograd became separated from the corresponding isotherm. Above the granulite-amphibolite isotherm rocks with granulite facies assemblages now occurred metastably (fig. 2b). The Nag. 1 deformation caused retrogression of the metastable granulite facies rocks above the isotherm and produced a strong planar fabric in the rocks (fig. 2c).

The Nag. 1 shearing also affected the gneisses north of Qáqatoqaq, between Kangerdluarssuk and Ikertôq. This will be further discussed when the Nag. 2 deformation is described. 


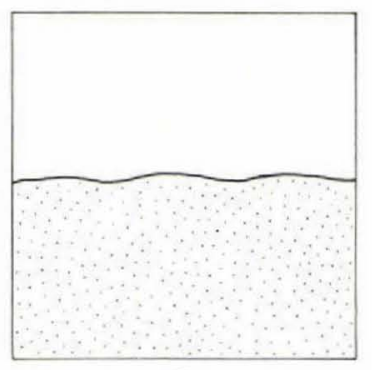

a
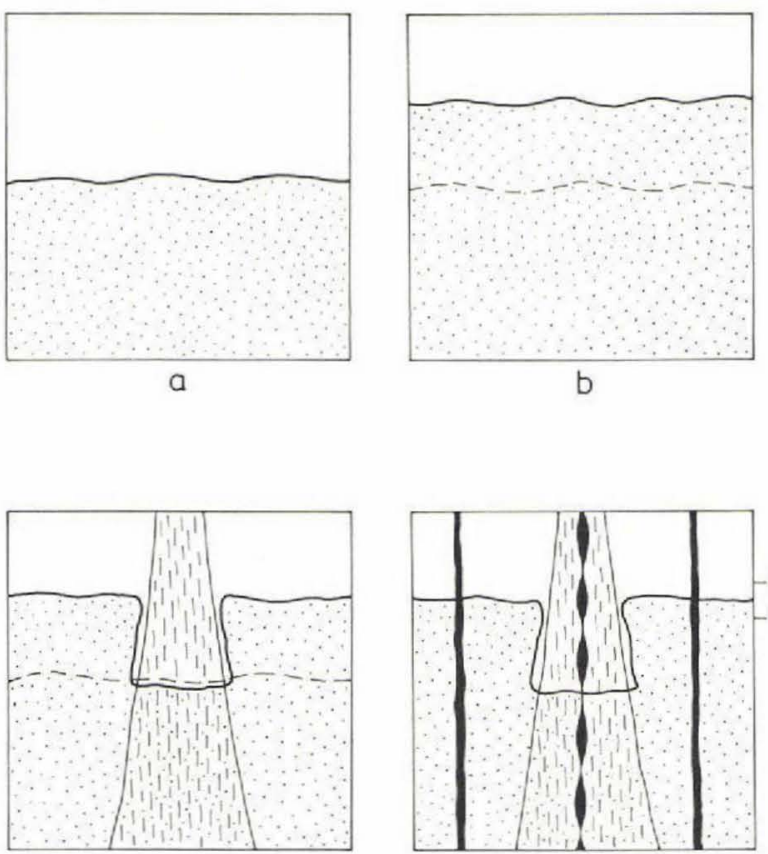

$\mathrm{C}$

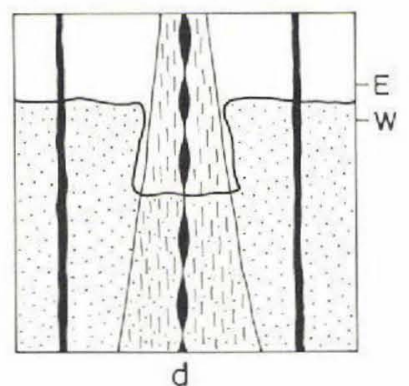

Fig. 2. Schematic, vertical, N-S sections through the crust across the Itivdleq shear zone. $a$ : The crust in Archaean times. The lower part of the section was stabilised in granulite facies (dotted), the upper part in amphibolite facies. $b$ : Uplift brought granulite facies assemblages into regions where they were metastable (dotted area above the dashed line). $c$ : Nag. 1 shearing (transcurrent along vertical shear planes) retrogressed the metastable granulite facies assemblages. $d$ : In the shear zone the Kangâmiut dykes intruded subparallel to the shear fabric and developed primary pinch \& swell structures. W and E indicate present erosion levels in western and eastern parts of Itivdleq.

\section{Dyke intrusion}

The Nag. 1 deformation was followed by the intrusion of the Kangâmiut dykes. In Qáqatoqaq and Nûgssûp qulâ the dykes are subvertical and trend mainly NE-SW and ESE-WNW (fig. 1) and non-consistency of cross-cutting relationships suggests that dykes of both trends are effectively of the same age. This is in agreement with findings of Escher, Jack \& Watterson (1976) from the western part of the coast south of Itivdleq, but in contrast to relations further south where NNE trending dykes consistently cross-cut E-W trending dykes (Escher, Sørensen \& Zeck, 1976; see however their figure 83).

The pattern of orientation of the dykes shows a marked change along Itivdleq where there is a concentration of E-W trending dykes (fig. 1). Field evidence clearly shows (Bridgwater, Escher, Nash \& Watterson, 1973; Watterson, 1974) that this change in trend is not due to a simple rotation of dykes from NE and WNW orientations by deformation, but is due to a primary change in the orientation of the fracture system into which the dykes intruded. Dykes outside as well as within the Itivdleq shear zone may be locally deformed marginally or in their central parts, but dyke shapes are not affected by deformation.

Whereas dykes in the Archaean gneisses in Nûgssûp qulâ and Qáqatoqaq are tabular in shape, highly continuous along their strike and clearly cross-cut the gneisses with sharp, angular contacts, the dykes in the Nag. 1 Itivdleq shear zone are subparallel to the Nag. 1 shear fabrics and may show a number of irregular shapes (pinch \& swell, pods \& lenses) and 
discontinuity along strike. The irregular shapes represent primary dyke forms since, except for the local deformation at the margins and central parts, the dykes are undeformed.

The northern limit of the Kangâmiut dyke swarm is on the islands just south of Holsteinsborg in the western part of the region (Grocott, 1977). In the eastern part, at the head of Ikertôq, the northern boundary is not yet established, but is north of the area shown in fig. 1.

\section{Metamorphic transitions in the Itivdleq area}

At this point it may be useful to emphasise that the metamorphic transition from granulite facies in Qáqatoqaq and Nûgssûp qulâ to low amphibolite facies along Itivdleq is in strong contrast to the metamorphic transition from granulite to amphibolite facies within the Qáqatoqaq and Nûgssûp qulâ areas. The only apparent change observed in the field and in thin sections when going from amphibolite to granulite facies in Nûgssûp qulâ and Qáqatoqaq is the appearance of hypersthene and the associated change in colour of the gneisses from greyish to brownish. The facies boundary is irregular and diffuse, patches of hypersthene-bearing rocks may be found within amphibolite facies rocks and vice versa.

The amphibolite-granulite facies transition in Qáqatoqaq and Nûgssûp qulâ is interpreted as a prograde metamorphic transition of Archaean age for the following reasons.

(1) The occurrence of undeformed dykes cross-cutting the facies boundary shows that the facies transition is pre-dyke in age and cannot be ascribed to post-dyke Nag. 2 amphibolite facies metamorphism (to be described later).

(2) The fact that the Nag. 1 deformation, as exemplified by the Itivdleq shear zone, retrogressed both granulite and amphibolite facies gneisses in Qáqatoqaq and Nûgssûp qulâ to low (epidote + muscovite) amphibolite facies, and created a structural trend oblique to structures both in amphibolite and granulite facies areas in Qáqatoqaq and Nûgssûp quâ, shows that the facies transition in these areas is pre-Nag. 1.

(3) The continuity of structures across the facies boundary in Qáqatoqaq and Nûgssûp qulâ shows that the facies transition is not caused by separate deformational events in the granulite and amphibolite facies areas.

(4) The only possible way of explaining the facies boundary as retrograde would be to claim that the retrogression was 'static'. Evidence quoted in favour of such an explanation are occurrence of 'relict' hypersthene in e.g. basic layers in amphibolite facies gneisses, 'relicts' of granulite facies gneisses in amphibolite facies gneisses, hypersthene rimmed by hornblende etc. (see Windley, 1972, p. 20-21).

In general, the concept of widespread static retrogression appears unacceptable in view of the chemical and mechanical problem, that the rehydration of a massive section of granulite facies rocks involves. Fyfe (1973, p. 460) estimates that a column of granulite $5 \mathrm{~km}$ thick and $1 \mathrm{~km}^{2}$ cross-section would require access by almost $1 \mathrm{~km}^{3}$ of fluid to be retrogressed to greenschist. Even though the granulite facies rocks considered here should only be retrogressed to upper amphibolite facies there seems to be no way of introducing such large amounts of fluid into massive granulite facies rocks without the aid of pervasive deformation like the kind observed in the Itivdleq shear zone.

As regards the occurrence of patches of granulite facies rocks in amphibolite facies areas, one must take into account that hypersthene is the only diagnostic mineral for granulite facies. The first occurrence of hypersthene in a prograde sequence depends on bulk rock 
compositions. For example in tonalitic rocks hypersthene will occur at a lower metamorphic grade than in rocks of granitic composition (Korstgård, 1978, 1979). Consequently areas of alkali feldspar bearing gneisses may occur in a granulite facies terrain without being recognised as granulite facies rocks when considered isolated. Furthermore, if increasing metamorphic grade is accepted to be related to depth of burial, diffuse or gradational facies boundaries with local occurrences of one adjacent facies in another are to be expected. In a similar way the occurrences of hornblende reaction rims at plagioclase-hypersthene interfaces may be explained, or they may be interpreted as local modifications of the high-grade assemblage during uplift, before the high-grade assemblage was completely frozen.

\section{Nag. 2 metamorphism and deformation}

Detailed structural studies in the coastal areas between Sagdlerssuaq and Manitsorssuaq by Grocott (1977, this volume) have shown that the strong planar E-W fabrics in the southern parts of these areas is mainly of Nag. 1 origin and that also in these areas the Kangâmiut dykes have intruded along Nag. 1 shear planes. The less detailed studies by the present writer in the fjord areas (Kangerdluarssuk and Qeqertalik) have confirmed these observations. However, the effects of the Nag. 1 deformation are partially masked by the subsequent Nag. 2 deformation and metamorphism. In the southernmost areas, along the north coast of Kangerdluarssuk and in Qeqertalik, the effects of Nag. 2 on the country gneisses are relatively slight and are mainly expressed as a folding of the Nag. 1 fabric around E-W subhorizontal axes. The effects on the dykes appear more severe. In addition to being folded together with the gneiss fabrics the dykes north of Kangerdluarssuk are completely converted into amphibolites with no traces left of the original mineralogy or microstructure. However, the dykes do not lose their identity as dykes and are clearly recognisable as intrusive bodies.

On the basis of the mineral assemblages of the metamorphosed dykes the area between Kangerdluarssuk and Maligiaq can be divided into three metamorphic zones (fig. 3).

\section{Hornblende zone}

This zone, extending from the north coast of Kangerdluarssuk to the south coast of Ikertôq (fig. 3), is characterised by the occurrence of hornblende as the sole ferro-magnesian mineral in the dykes. The original igneous augite + plagioclase assemblage has been completely converted to a metamorphic hornblende + plagioclase assemblage. The colour of the hornblende is typically blue-green in Qeqertalik changing to grass-green in Avatdleq (fig. 3). Plagioclase has an anorthite content corresponding to oligoclase-andesine (fig. 4). Sphene is an ubiquitous accessory, replacing igneous ilmenite, and quartz is present in minor amounts.

The association of the major phases of the metadolerites in the hornblende zone is shown in an ACF diagram in fig. 3 where also 11 analysed metadolerites from the hornblende zone are plotted. The assemblage plagioclase + hornblende dominates completely, only one metadolerite containing clinopyroxene and two with garnet were found in this zone (fig. 3 ).

The typical mineral assemblage in the country gneisses is quartz + alkali feldspar + 


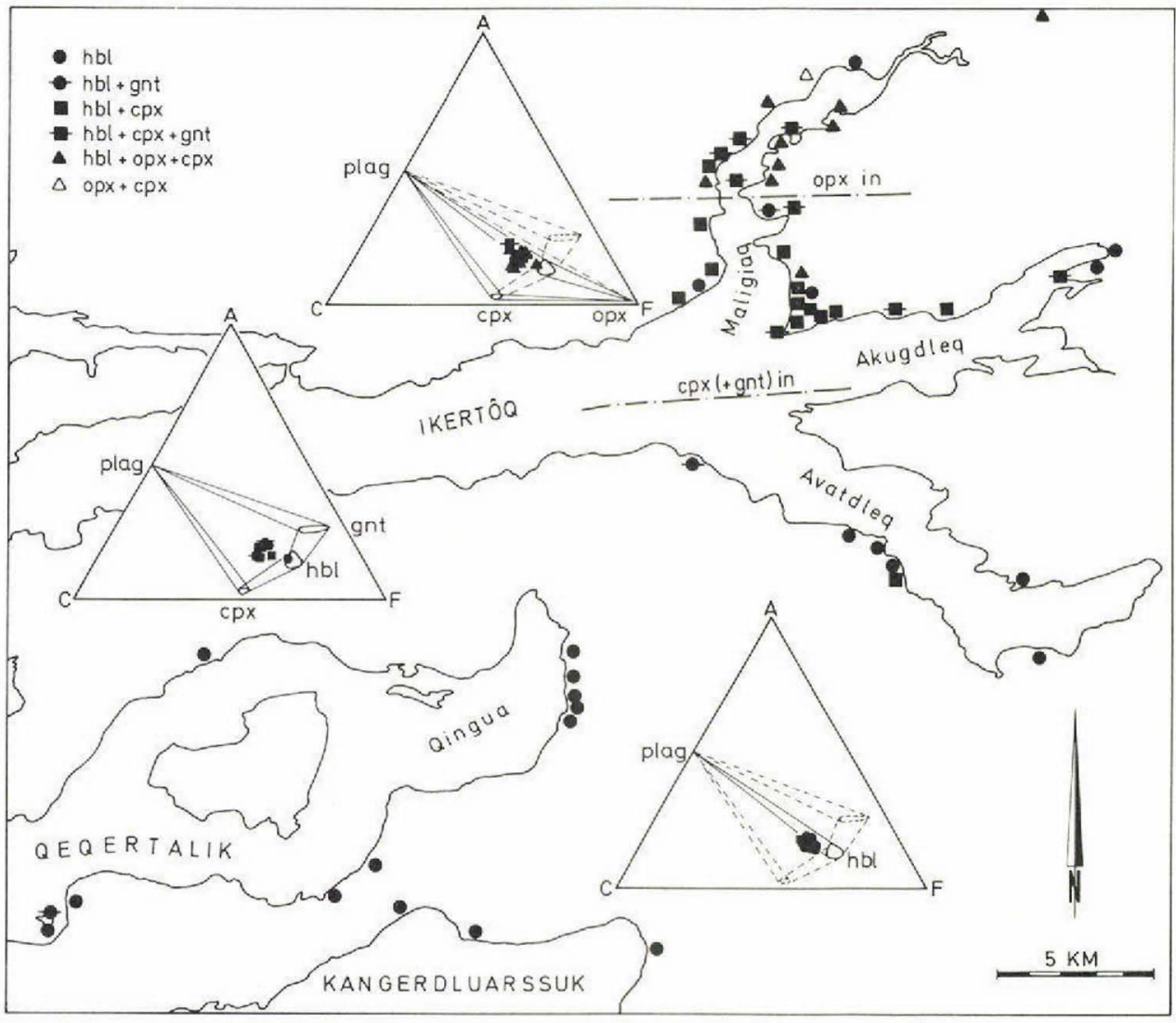

Fig. 3. Map of the Kangerdluarssuk-Maligiaq area showing location and mineral assemblages of the investigated dykes. The dash-dot line marked 'cpx + (gnt) in' marks the southern limit of the garnet-clinopyroxene zone. The line 'opx in' marks the southern limit of the orthopyroxene zone. The ACF diagrams show, from south to north, the mineral parageneses in the hornblende zone, the garnet-clinopyroxene zone, and the orthopyroxene zone respectively. Analysed dykes from the three zones are plotted in the corresponding diagrams.

plagioclase + green-brown biotite + epidote. Other common minerals are blue-green hornblende and muscovite (fig. 4).

Structurally the rocks in the hornblende zone are characterised by intermediate (outcrop scale) to large scale folding, around E-W trending subhorizontal axes, of the earlier Nag. 1 fabrics and the metadolerites. No new fabrics can be related to these folds so possibly the mineral assemblage found in the gneisses is of Nag. 1 parentage. Further north, in Avatdleq, Nag. 2 deformation becomes more intense and modifies the Nag. 1 fabric. A detailed account of the relationship between Nag. 1 and Nag. 2 deformation in the coastal areas is given by Grocott (1977; this volume). 
DYKES

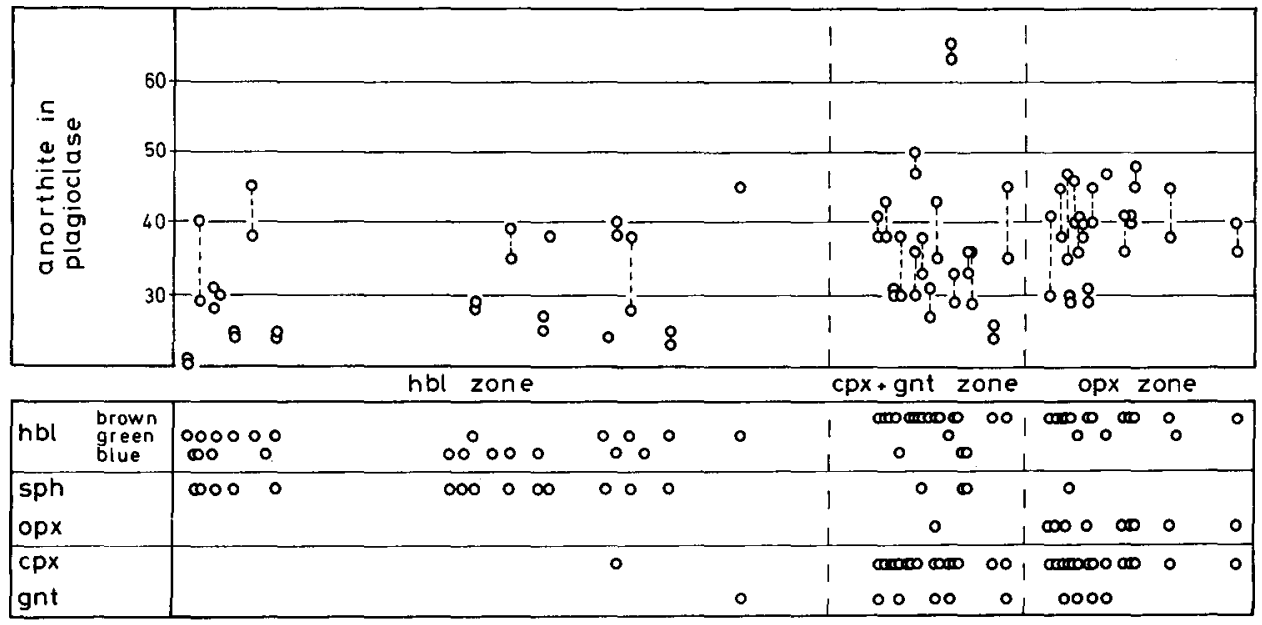

GNEISSES

\begin{tabular}{|c|c|c|c|c|c|c|c|c|c|c|c|c|c|c|}
\hline \multicolumn{2}{|c|}{ alk - fsp } & \multirow{2}{*}{0} & \multirow{2}{*}{$\infty$} & \multirow{2}{*}{0} & \multirow{2}{*}{$\infty$} & \multirow[b]{2}{*}{0} & \multirow{2}{*}{0} & \multirow{2}{*}{\multicolumn{2}{|c|}{$\begin{array}{ll}0 & 0 \\
0.0 & 0 \\
\end{array}$}} & \multirow{2}{*}{00} & \multirow{2}{*}{$\frac{01}{01}$} & 000000 & \multicolumn{2}{|l|}{$0 \mathrm{cos}$} \\
\hline bio & $\begin{array}{l}\text { red } \\
\text { brown } \\
\text { green }\end{array}$ & & & & & & & & & & & $\begin{array}{l}0 \\
0 \infty 00 \\
0 \infty \infty\end{array}$ & 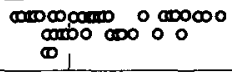 & 0 \\
\hline hbl & $\begin{array}{l}\text { brown } \\
\text { green } \\
\text { blue }\end{array}$ & & & 0 & $0^{\circ}$ & 0 & 0 & 0 & & 0 & $\begin{array}{l}1 \\
1\end{array}$ & - $\infty$ & 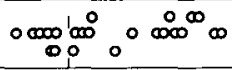 & \\
\hline $\begin{array}{l}\text { mus } \\
\text { epd }\end{array}$ & & 0 & $\infty$ & $\begin{array}{r}0 \\
\infty\end{array}$ & o & 0 & & 0 & $\infty$ & 00 & 1 & $0 \infty$ & 1 & \\
\hline $\begin{array}{l}\text { opx } \\
\text { cpx } \\
\text { gnt }\end{array}$ & & & & & & & & & & & $\begin{array}{l}1 \\
1 \\
1\end{array}$ & $0^{0}$ & 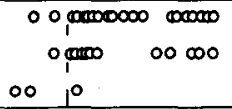 & 0 \\
\hline $\mathrm{K}$ & EROL & $3=$ & & & & $\alpha \in$ & $R / A$ & LIK & & & RTOQ & & MALIGIAQ & \\
\hline
\end{tabular}

Fig. 4. Diagrams showing the variation in mineral content in dykes and country gneisses and the variation of the anorthite content of plagioclase in meta-dykes along a south to north line from Kangerdluarssuk to Maligiaq (see fig. 3). Abbreviations: hbl - hornblende, sph - sphene, opx - orthopyroxene, cpx - clinopyroxene, gnt - garnet, alk-fsp - alkali feldspar, mus - muscovite, epd - epidote.

\section{Garnet-clinopyroxene zone}

In the area between the south coast of Ikertôq and halfway into Maligiaq (fig. 3) clinopyroxene and garnet commonly occur in addition to hornblende and plagioclase in the metadolerites. The most common assemblage found in this zone is plagioclase + hornblende + clinopyroxene \pm garnet whereas plagioclase + hornblende \pm garnet is rare. Sphene may occur as an accessory, but is mostly replaced by ilmenite. The colour of hornblende has changed from grass-green to brown-green and the anorthite content of plagioclase has increased to 30-40 per cent (fig. 4). The ACF diagram corresponding to this zone (fig. 3) does not indicate that bulk composition has any influence in determining whether 
clinopyroxene or garnet is produced from the breakdown of hornblende and the determining factors are more likely local variations in water pressure and silica activity (Glassley \& Sørensen, 1979 and this volume).

In the host gneisses epidote has disappeared (fig. 4) and only traces of muscovite are present. The typical assemblage is quartz + alkali feldspar + plagioclase + brown biotite. Green hornblende, clinopyroxene and garnet may occur as additional phases.

The Nag. 2 folds in the garnet-clinopyroxene zone are tight to isoclinal with an axial-plane schistosity dipping steeply to the NNW. Dykes are often broken up into lenses on what appear to be the limbs of the major folds. Fold axes and linear structures plunge shallowly to the WNW. In the northern part of the garnet-clinopyroxene zone there is an abrupt change in the plunge of the linear structures to steeply down dip (NNW). This change in the orientation of the linear structures is associated with a steep strain gradient as evidenced by the development of a strong planar fabric in the gneisses (fig. 1). The Nag. 2 deformation here is interpreted as a zone of strong deformation characterised by ductile overthrusting towards the SSE on a moderately steep shear plane.

\section{Orthopyroxene zone}

The appearance of orthopyroxene in meta-dykes and gneisses marks the transition from amphibolite to granulite facies. The orthopyroxene zone extends from halfway into Maligiaq to as far north as has been mapped (fig. 3) and is characterised by the occurrrence of orthopyroxene in all rocks of suitable compositions. The most common assemblage in the metadolerites is plagioclase + hornblende + orthopyroxene + clinopyroxene. Less common is plagioclase + hornblende + clinopyroxene + garnet whereas plagioclase + hornblende \pm clinopyroxene assemblages are rare. A single metadolerite with the anhydrous assemblage plagioclase + orthopyroxene + clinopyroxene was found. Sphene is no longer present, hornblende is typically brown, and the anorthite content of plagioclase has increased further to around 40 per cent (fig. 4). The various mineral assemblages found in this zone are outlined in the ACF diagram in fig. 3.

In quartzo-feldspathic gneisses the typical mineral association is quartz + plagioclase + red-brown biotite + brown-green hornblende + orthopyroxene + clinopyrox ne (fig. 4). The almost complete disappearance of alkali feldspar is puzzling as it cannot be attributed to any alkali feldspar consuming reaction in the gneisses. It is associated with a significant drop in the potassium content of the gneisses which must be either a primary feature or connected with metasomatic or partial melting processes. The facies transition in Maligiaq is very sharp and takes place in both dykes and gneisses within a few hundred metres.

The structures in the orthopyroxene zone are similar to those described for the northern part of the garnet-clinopyroxene except that within the orthopyroxene zone strips of low strain alternate with strips of high strain as typical of the overthrusting zone. In the inner parts of Maligiaq the strain again decreases as the northern boundary of the Nag. 2 overthrusting zone is reached (fig. 1). However, Nag. 2 deformation and metamorphism continues northwards since the Kangâmiut dykes also north of the Nag. 2 overthrusting zone are deformed and metamorphosed.

In Maligiaq the amphibolite-granulite facies boundary is parallel to the overthrusting zone in the horizontal as well as in the vertical plane. However, the facies boundary does not 
coincide with the deformation boundary but lies within the overthrusting zone. The abrupt nature of the facies transition and the parallelism of facies and deformation boundaries clearly shows that the two are closely related.

\section{Types of facies transitions in the Itivdleq-Ikertôq region}

Within the Itivdleq-Ikertôq region three types of facies transitions or boundaries are recognised. Two of these are prograde and two are associated with strong deformation in ductile shear zones.

The amphibolite-granulite facies transition in the Archaean areas of Qáqatoqaq and Nûgssûp qulâ is prograde and static in the sense that the boundary was not established as a result of a deformational event, but reflects static equilibration of the mineral assemblages to the conditions that prevailed when the rocks were at their deepest crustal level. During later uplift the rocks escaped any significant metamorphic changes due to absence of deformation.

The granulite to low amphibolite facies and amphibolite to low amphibolite facies transitions along Itivdleq (Nag. 1) are retrograde and dynamic in the sense that they were established as a direct consequence of the transcurrent shearing in the Itivdleq shear zone. Mineral assemblages in the shear zone were equilibrated to the metamorphic conditions of a higher crustal level and the shearing triggered this re-equilibration. It is worth noting here that at a deeper erosional level of the Itivdleq shear zone the deformation boundaries of the shear zone will not correspond to any metamorphic facies boundaries (cf. fig. 2c). At a deeper level it may even be that a static prograde facies boundary is found across the shear zone as in the Nordre Strømfjord shear zone (Bak, Korstgård \& Sørensen, 1975). However, the deformation boundaries will still be evident.

The amphibolite-granulite facies transition in Maligiaq (Nag. 2) is both prograde and dynamic. It can be considered as a displaced prograde and static transition brought up in a subvertical position by the overthrust movement. Its position at the present level of erosion is clearly a result of deformation. Because of the nature of a thrust (rocks from a deeper crustal level are brought up on the overthrust side and a greater load is placed on rocks on the underthrust side) regions bounding a ductile overthrusting shear zone will suffer metamorphic and deformational effects not experienced by regions adjacent to ductile shear zones with transcurrent movements. Regions bounding these are largely unaffected by the shearing.

\section{Summary of structural and metamorphic evolution}

On the basis of the preceding description and discussion of the metamorphism and deformation in the Itivdleq-Ikertôq area as well as on previous contributions (Watterson, 1974; Bak et al., 1975; Grocott, 1977) the following model for the structural and metamorphic evolution at the southern Nagssugtoqidian boundary is proposed.

(1) In Archaean times rocks now exposed were stabilised in granulite facies in western areas and in amphibolite facies in eastern areas (fig. 2a \& 5a).

(2) Uplift brought rocks now exposed to crustal levels where granulite and upper amphibolite facies assemblages were metastable (fig. 2b).

(3) Nag. 1 shearing, mainly transcurrent, produced the Itivdleq shear zone (fig. 2c) and 

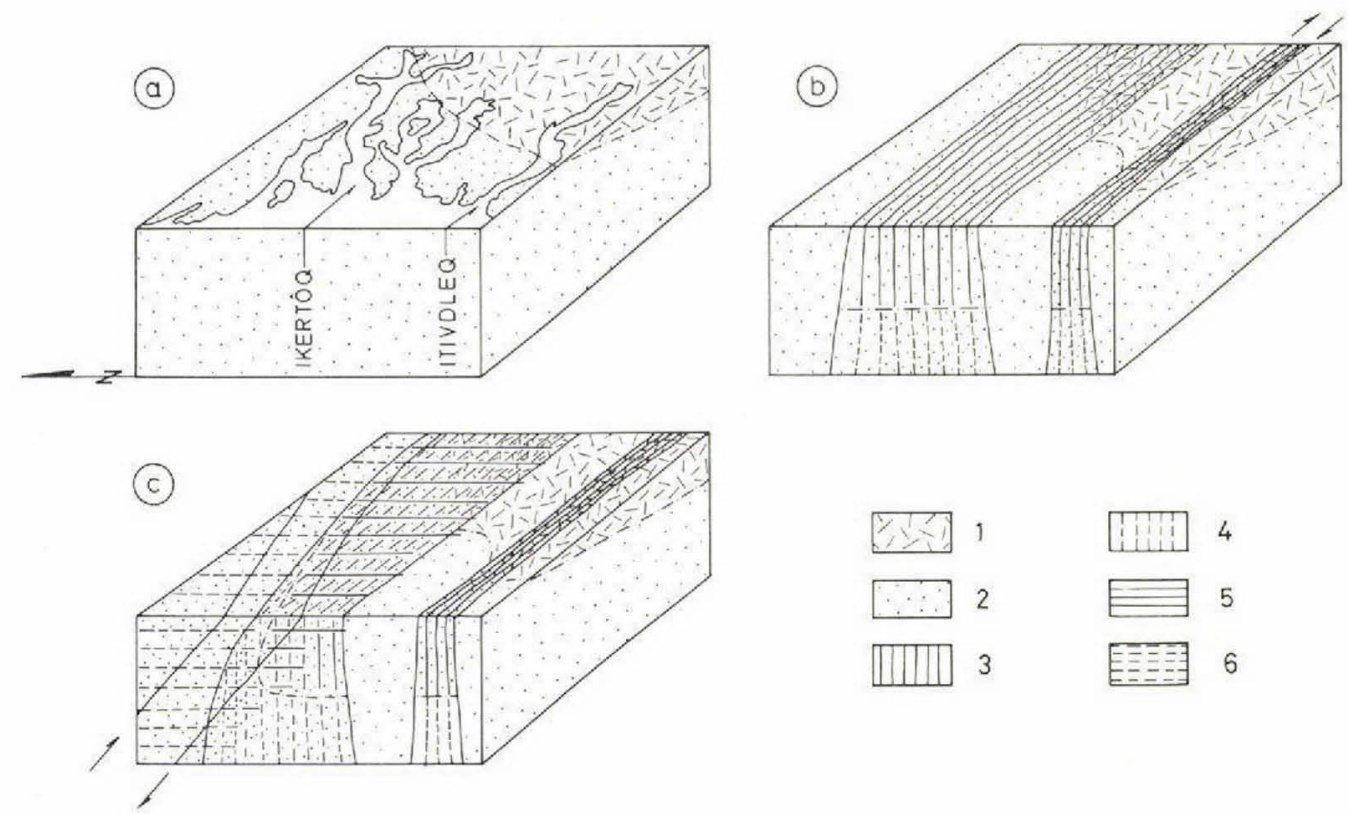

Fig. 5. Block diagrams summarising the structural and metamorphic development of the Itivdleq-Ikertôq region. The top surface represents the present erosional level in all three diagrams. Dash-dot line in the diagrams marks the amphibolite-granulite facies transition. $a$ : Stabilisation of the rocks in granulite and amphibolite facies in the Archaean. $b$ : Nag. 1 shearing in Itivdleq and possible extent of Nag. 1 shearing north of Itivdleq. $c$ : Nag. 2 ductile overthrusting along Ikertôq and Nag. 2 deformation and metamorphism in regions bounding the thrust zone. Ornaments: 1. Archaean amphibolite bacies; 2 . Archaean granulite facies; 3. Nag. 1 amphibolite facies; 4 . Nag. 1 granulite facies; 5. Nag. 2 amphibolite facies; 6. Nag. 2 granulite facies.

most likely a similar shear zone further north between Kangerdluarssuk and Ikertôq (fig. 5 b). In the shear zones rocks now exposed suffered shearing under low amphibolite facies conditions and recrystallised to form new fabrics and equilibrium assemblages.

(4) Following the Nag. 1 shearing the crust between Sukkertoppen and Holsteinsborg was invaded by swarms of dolerite dykes, the Kangâmiut dykes. In Archaean rocks the dykes intruded along NE-SW and WNW-ESE ductile 'fractures' (Escher et al., 1976) and in Nag. 1 -affected rocks they intruded subparallel to Nag. 1 planar fabrics where they developed primary pinch \& swell structures (fig. 2 d). Although the Nag. 1 shear zones clearly pre-date the dyke intrusion there is also good field evidence (Grocott, 1977) that the Nag. 1 zones were also active during and after dyke emplacement.

(5) Major post-Kangâmiut dyke deformation and metamorphism (Nag. 2) is only recorded north of Kangerdluarssuk. Relatively low Nag. 2 strain produced folding of Nag. 1 fabrics and Kangâmiut dykes and metamorphism to amphibolite facies of Kangâmiut dykes in Kangerdluarssuk, Qeqertalik and Ikertôq. Nag. 2 deformation culminated in an ENE trending zone of ductile overthrusting towards the SSE and brought, at the level now 


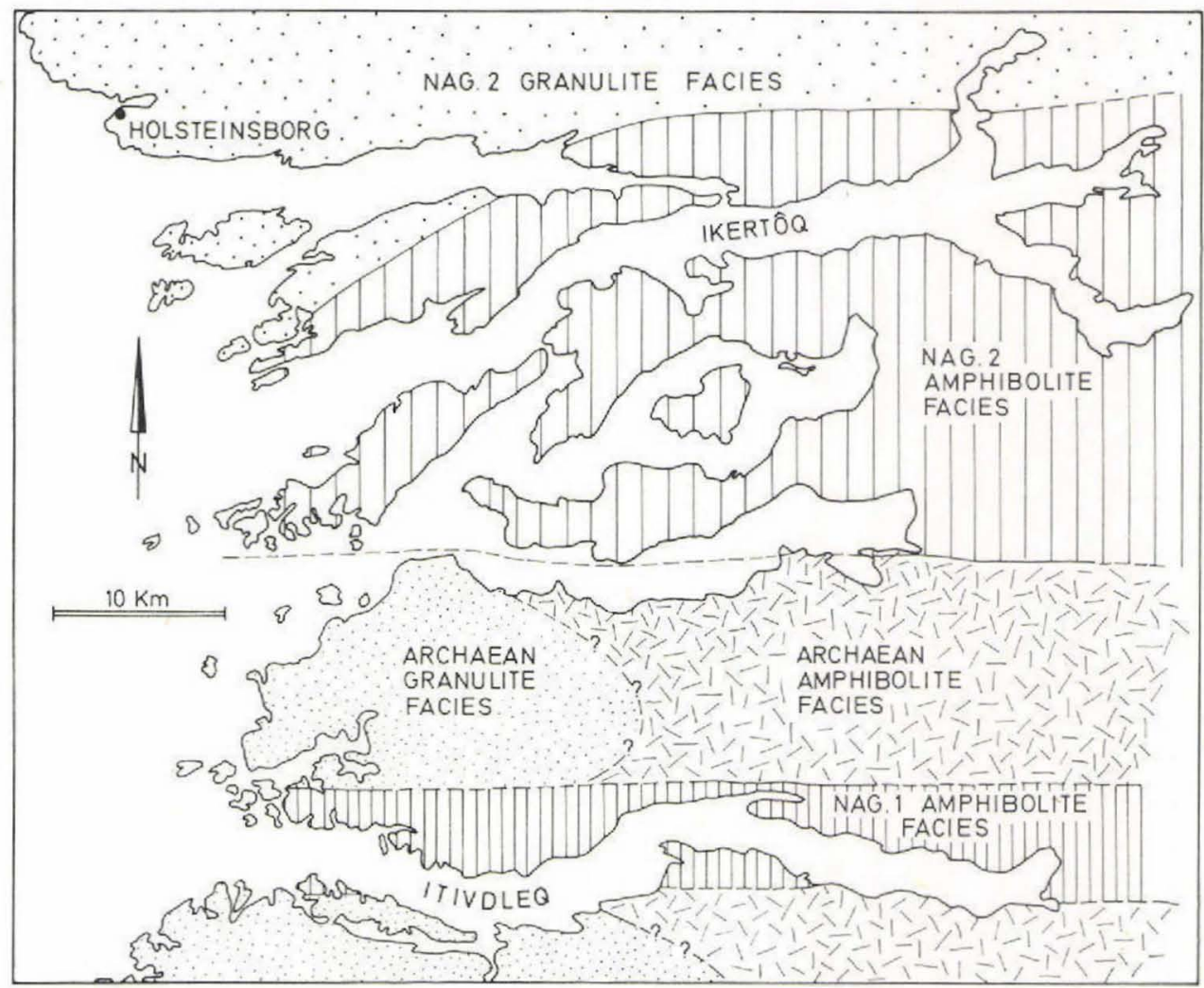

Fig. 6. Distribution and relative ages of metamorphic facies in the Itivdleq-Ikertôq region.

exposed, granulite facies rocks up into juxtaposition with lower grade rocks thereby creating a telescoping effect on metamorphic facies boundaries (fig. $5 \mathrm{c}$ ).

The distribution and relative age of metamorphic facies in the Itivdleq-Ikertô region is outlined in fig. 6 . The distinction between the relative ages of the metamorphic and structural events that led to this distribution is primarily made possible by the occurrence of the Kangâmiut dykes.

The Itivdleq-Ikertôq region represents a part of the Precambrian crust characterised by repeated reworking with very little addition of new crustal material in a time span of possibly $1200 \mathrm{Ma}$ (Hickman, this volume; Kalsbeek, this volume).

Hickman (this volume) reports a preliminary whole rock Rb-Sr age of about $3000 \mathrm{Ma}$ for granulite facies gneisses around Holsteinsborg. These rocks received their present equilibrium assemblage in post-Kangâmiut dyke time (Davidson, 1978). Since an age of $1950 \mathrm{Ma}$ (Kalsbeek et al., 1978) has been determined for the time of intrusion of the Kangâmiut dykes, the geological evidence presented by Grocott (1977; this volume) and in this paper calls for a very careful interpretation of radiometric ages obtained for the gneisses in the Itivdleq-Ikertôq region. 
Acknowledgements. The work in the Holsteinsborg-Itivdleq region was undertaken as part of the Liverpool Precambrian Boundary Programme led by Juan Watterson. Field work in the area was supported by Statens naturvidenskabelige Forskningsråd. I am grateful to my colleagues at Liverpool and Aarhus for helpful discussion.

\section{References}

Bak, J., Korstgård, J. A. \& Sørensen, K. 1975: A major shear zone within the Nagssugtoqidian of West Greenland. Tectonophysics 27, 191-209.

Bak, J., Sørensen, K., Grocott, J., Korstgård, J. A., Nash, D. \& Watterson, J. 1975: Tectonic implications of Precambrian shear belts in western Greenland. Nature 254, 566-569.

Bridgwater, D., Escher, A., Nash, D. F. \& Watterson, J. 1973: Investigations on the Nagssugtoqidian boundary between Holsteinsborg and Kangâmiut, central West Greenland. Rapp. Grønlands geol. Unders. 55, 22-25.

Davidson, L. M. 1978: Granulite facies rocks bordering the Ikertôq shear belt, central West Greenland. Unpublished Ph.D. Thesis, Liverpool University.

Escher, A., Jack, S. \& Watterson, J. 1976: Tectonics of the North Atlantic Proterozoic dyke swarm. Phil. Trans. R. Soc. Lond. A, 280, 529-539.

Escher, A., Sørensen, K. \& Zeck, H. P. 1976: Nagssugtoqidian mobile belt in West Greenland. In Escher, A. \& Watt, W. S. (edit.) Geology of Greenland, 77-85. Copenhagen: Geol. Surv. Greenland.

Fyfe, W. S. 1973: The granulite facies, partial melting and the Archaean crust. Phil. Trans. R. Soc. Lond. A, 273, 457-461.

Glassley, W. \& Sørensen, K. 1979: Constant $P_{\mathbf{s}}-T$ amphibolite to granulite facies transition in Agto (West Greenland) metadolerites: implications and applications. J. Petrol. (in press).

Glassley, W. \& Sørensen, K. 1979: The effects of solid and vapour phase compositional variations on the amphibolite facies to granulite facies transition in the Agto metadolerites. Rapp. Grønlands geol. Unders. 89 (this volume).

Grocott, J. 1977: The northern boundary of the Ikertôq shear belt, West Greenland. Unpublished Ph.D. Thesis, Liverpool University.

Grocott, J. 1979: Controls of metamorphic grade in shear belts. Rapp. Grønlands geol. Unders. 89 (this volume).

Hickman, M. H. 1979: A Rb-Sr age and isotope study of the Ikertôq, Nordre Strømfjord, and Evighedsfjord shear belts, West Greenland - outline and preliminary results. Rapp. Grønlands geol. Unders. 89 (this volume).

Kalsbeek, F. 1979: Rb-Sr evidence on the age of the Nagssugtoqidian orogeny in West Greenland, with remarks on the use of the term 'Nagssugtoqidian'. Rapp. Gronlands geol. Unders. 89 (tlis volume).

Kalsbeek, F., Bridgwater, D. \& Zeck, H. P. 1978: A 1950 ( \pm 60) Ma Rb-Sr whole-rock isochron age from two Kangâmiut dykes and the timing of the Nagssugtoqidian (Hudsonian) orogeny in West Greenland. Can. J. Earth Sci. 15, 1122-1128.

Korstgård, J. A. 1978: Petrography and geochemistry of Nagssugtoqidian granulite-facies gneisses from the Inugsuk area, Nordre Strømfjord region, West Greenland. Unpublished lic. scient. thesis, Aarhus University.

Korstgård, J. A. 1979: Compositional controls on mineral assemblages in quartzo-feldspathic granulite-facies gneisses. Neues $J b$. Miner. Abh. 135, 113-131.

Watterson, J. 1974: Investigations on the Nagssugtoqidian boundary in the Holsteinsborg district, central West Greenland. Rapp. Grønlands geol. Unders. 65, 33-37.

Windley, B. F. 1972: Regional geology of early Precambrian high-grade metamorphic rocks in West Greenland. Rapp. Grønlands geol. Unders 46, 46 pp.

Geologisk Institut,

Aarhus Universitet,

8000 Arhus C,

Denmark. 